\title{
Mortality event in freshwater drum Aplodinotus grunniens from Lake Ontario, Canada, associated with viral haemorrhagic septicemia virus, Type IV
}

\author{
J. S. Lumsden ${ }^{1, *}$, B. Morrison ${ }^{2}$, C. Yason $^{3}$, S. Russell ${ }^{1}$, K. Young ${ }^{1}$, A. Yazdanpanah ${ }^{1}$, \\ P. Huber ${ }^{1}$, L. Al-Hussinee ${ }^{1}$, D. Stone ${ }^{4}$, K. Way ${ }^{4}$ \\ ${ }^{1}$ Fish Pathology Laboratory, Department of Pathobiology, Ontario Veterinary College, University of Guelph, Guelph, \\ Ontario N1G 2W1, Canada \\ ${ }^{2}$ Ontario Ministry of Natural Resources, Lake Ontario Management Unit, Glenora Fisheries Station, RR\#4 Picton, \\ Ontario KOK 2Y0, Canada \\ ${ }^{3}$ Department of Pathology and Microbiology, Atlantic Veterinary College, University of Prince Edward Island, \\ Prince Edward Island C1A 4P3, Canada \\ ${ }^{4}$ CEFAS Weymouth Laboratory, Barrack Rd., The Nothe, Weymouth, Dorset DT4 8UB, UK
}

\begin{abstract}
A mortality event primarily affecting freshwater drum Aplodinotus grunniens was noted during April and May 2005 in the Bay of Quinte, Lake Ontario, Canada. A conservative estimate of the number of dead drum was approximately 100 metric tonnes. Large numbers of dead round goby Neogobius melanostomus were also seen, as well as a few muskellunge Esox masquinongy. In the drum, there was a consistent histological pattern of variably severe panvasculitis, a necrotising myocarditis, meningoencephalitis and a segmental enteritis. Moderate numbers of bullet-shaped viral particles consistent with a rhabdovirus were identified by transmission electron microscopy (TEM) in affected heart tissue. Following primary isolation from pooled tissues on fathead minnow (FHM) cells, a morphologically similar virus, $\sim 165 \times 60 \mathrm{~nm}$ in size, was visualised. Identification of the isolate as viral haemorrhagic septicemia virus (VHSV) was confirmed by enzyme immunoassay and by polymerase chain reaction. An appropriately sized product (468 bp) of the G-glycoprotein gene (nucleotides [nt] 340 to 807) was generated with RNA extracted from FHM cell supernatant. Analysis of a $360 \mathrm{nt}$ partial glycoprotein gene sequence (nt 360 to 720 ) indicated a 96.4 to $97.2 \%$ nucleotide identity with known strains of North American (NA) VHSV. Analysis using Neighbour-joining distance methods assigned the isolate to the same lineage as the NA and Japanese isolates (Genogroup IV). However, there was sufficient sequence divergence from known NA VHSV isolates to suggest that this isolate may represent a distinct subgroup. The effects of ongoing mortality in freshwater drum and in multiple species during spring 2006 suggest that this newly recognised virus in the Great Lakes will have continued impact in the near future.
\end{abstract}

KEY WORDS: Freshwater drum - Aplodinotus grunniens · Viral haemorrhagic septicemia virus . VHSV · Genogroup IV · Vasculitis · Meningoencephalitis · Necrotising myocarditis · Enteritis

\section{INTRODUCTION}

Viral haemorrhagic septicemia virus (VHSV), a rhabdovirus of the Norvirhabdoviridae (Walker et al. 2000), is divided into 4 genogroups based on sequencing of the nucleoprotein $(\mathrm{N})$ and glycoprotein $(\mathrm{G})$ genes (Einer-Jensen et al. 2004, Snow et al. 2004).
Moreover, these genogroups roughly correlate with geographic distribution (Snow et al. 1999). Genogroup I includes the Egtved virus and other freshwater isolates, as well as some marine isolates from the Baltic Sea. Genogroup IV includes all of the North American (NA) and the vast majority of the Pacific Ocean isolates examined to date (Stone et al. 1997, Snow et al. 1999, 
Nishiziwa et al. 2002). In NA, a VHSV Genogroup IV was first isolated from returning Chinook Oncorhynchus tshawytscha and coho O. kisutch salmon (Brunson et al. 1989, Hopper 1989, Winton et al. 1989) and subsequently has been isolated on numerous occasions from a variety of apparently normal marine fish (Meyers \& Winton 1995). Epizootics have been described in herring Clupea pallasi, hake Merluccius productus and pollock Theragra chalcogramma in Alaska (Meyers et al. 1999), as well as herring C. pallasi, pilchards Sardinops sagax and black cod Anoplopoma fimbria in British Columbia (Traxler et al. 1999). Subsequent surveillance has documented the species and geographical range extensions in healthy fish in Pacific coastal waters (Hedrick et al. 2003). It has been proposed that VHSV has likely been historically present in Pacific NA marine waters and may have been involved in epizootics in Pacific sardines in British Columbia (Sindermann 1990). A major feature of VHSV is the broad range of species affected, both in fresh and marine water, with a total of at least 48 species recorded to date (Skall et al. 2005). More recently, VHSV was isolated from several species, including brown trout Salmo trutta, in brackish water from the Canadian Atlantic coast (Olivier 2002).

Transmission of VHSV is predominantly horizontal, chiefly via the gill epithelium (Chilmonczyk et al. 1995); vertical transmission has not been demonstrated. Rainbow trout Oncohynchus mykiss surviving experimental infection become asymptomatic carriers, and virus is shed in the urine and ovarian fluids (Neukirch 1986). Numerous marine fish species including Pacific herring are considered to be reservoirs of VHSV (Skall et al. 2005). The virus shows tropism for endothelium, but also for leukocytes, particularly macrophages, depending on the species/ model used for study (Evensen et al. 1994, Chilmonczyk et al. 1995, Brudeseth et al. 2002). The tropism for endothelium results in widespread vascular involvement and lesions in, potentially, any organ. Clinically there are acute, chronic and nervous forms of infection, descriptively complicated by the broad species range and reflective of the body systems predominantly affected and likely the degree of innate (Dorson et al. 1995) and acquired immunity (Lorenzen et al. 2001). The characteristic lesions associated with VHSV infection in salmonids are haemorrhage, with renal interstitial and splenic necrosis (Evensen et al. 1994), while in marine herring, turbot, etc. the target organs are the heart, brain, kidney and spleen and to a lesser degree the intestine (Marty et al. 1998, Isshiki et al. 2001, Brudeseth et al. 2005).

The present report will describe the identification of VHSV Genogroup IV as the putative cause of death in freshwater drum Aplodinotus grunniens during a mor- tality event in Lake Ontario in the spring of 2005. The repeated recognition of VHSV Type IV in the lower Great Lakes (recorded in Lakes Erie, Ontario and Lake St. Clair in 2006) has numerous implications for native populations of fish, for stocking programmes and collection of broodstock and, potentially, for aquaculture.

\section{MATERIALS AND METHODS}

Fish. Two separate submissions of 5 adult drum Aplodinotus grunniens shipped on ice were received for examination. These fish were collected alive from the Bay of Quinte, Lake Ontario, Canada, several hours earlier that same day. Fish of any size showing lethargic behaviour and/or disorientation were targeted. The fish captured averaged $3 \mathrm{~kg}$ and 50 to $55 \mathrm{~cm}$ in total length, and both sexes were affected. Water temperatures averaged $\sim 11^{\circ} \mathrm{C}$ during mid-May when fish were collected.

Mortality estimate. An exponential and a double exponential function were used to model drum mortality. Each model allows for rapid increases in fish deaths followed by decreasing mortality that may not ever reach zero. With only 4 observations of ' $y$ ', model fitting was done iteratively using a spreadsheet with manual changes to parameters. Model fitting also focused on the latter 3 points as sampling effort increased with time. The model forms used were: $y=$ $c t \mathrm{e}^{-\lambda t}$ for Model 1 and $y=c\left(\mathrm{e}^{-\lambda_{1} t}-\mathrm{e}^{-\lambda_{2} t}\right)$ for Model 2, where $y$ is the number of fish dying, $c$ is the constant adjusting magnitude of curve, $t$ is time (d) and for Model 2, $0<\lambda_{1}<\lambda_{2}$ are rate parameters (Gentry 1978). Model 1 was compared with 2 start dates, April 22 and April 26, and Model 2 was run with April 26 as the start date, because the start date was estimated based on anecdotal descriptions (Fig. 1). Statistical model fitting was not performed since there were only 4 observations with variable levels of effort. At each time point both dead and dying fish were counted at a separate location distant from sites used previously.

Pathology and histology. Wet mounts were prepared from gill biopsies and skin scrapes from all fish. Tissues were fixed in $10 \%(\mathrm{v} / \mathrm{v})$ buffered formalin, processed by routine methods, sectioned at $5 \mu \mathrm{m}$ and stained with haematoxylin and eosin (H\&E). ZiehlNeelsen, Giemsa, periodic-acid Schiff, Brown and Brenn modified Gram and Warthin Starry stains were performed on selected tissues.

Transmission electron microscopy. Various fresh tissues were fixed in $2.5 \%$ glutaraldehyde in $0.1 \mathrm{M}$ cacodylate buffer, pH 7.34 (CB) (Marivac Ltd.), for $1 \mathrm{~h}$ at $20^{\circ} \mathrm{C}$ and stored overnight at $4^{\circ} \mathrm{C}$. After being washed in $\mathrm{CB} 1 \mathrm{~h}$ at $20^{\circ} \mathrm{C}$, tissues were placed in $2 \%$ $\mathrm{OsO}_{4}$ for post-fixation (Hayat 1970). Tissues were then 


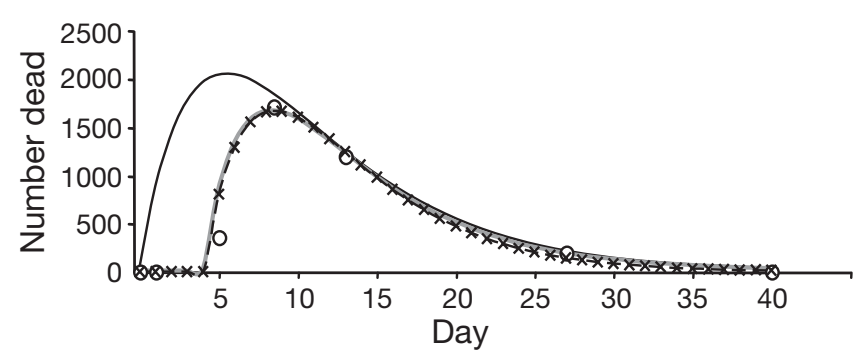

\begin{tabular}{|c|c|c|c|}
\hline Exponential model & Constant & $\begin{array}{c}\text { Rate } \\
\text { parameters }(\lambda)\end{array}$ & $\begin{array}{c}\text { Number } \\
\text { dead }\end{array}$ \\
\hline $\begin{array}{c}\text { Single, April 22 start } \\
\text { Single, April 26 start } \\
--\star--\end{array}$ & 1000 & 0.18 & 30607 \\
\hline \begin{tabular}{c} 
Double, April 26 start \\
\hline
\end{tabular} & 6000 & $0.15,0.325$ & 21284 \\
\hline
\end{tabular}

Fig. 1. Modelling results of the Lake Ontario drum mortality event using exponential and double exponential functions. The number of dead drum is on the vertical axis and confirmed observations are graphed as circles. Day 0 represents a start date of April 22, 2005

washed in CB and dehydrated with an ethanol series $(20,50,70,80,90,95 \%$ ethanol, $30 \mathrm{~min}$ each, and $100 \%$ for $1 \mathrm{~h}$ with 3 changes). The intermediate solvent propylene oxide (PO) (99\%, Acros Organics) was used to promote infiltration of Tabb embedding resin (Marivac). The infiltration series was 1:1 PO/ethanol, $100 \%$ PO; 1:4, 1:3, 1:2 epon/PO, 100\% epon overnight. Tissues were transferred to labelled embedding moulds, and fresh epon was added. The embedded tissues were cured for $48 \mathrm{~h}$ at $58^{\circ} \mathrm{C}$. After curing, $0.5 \mu \mathrm{m}$ sections were cut using a Reichert-Jung ultracut E ultramicrotome (Leica Microsystems) and a Diatome histo diamond knife (Diatome US), heat-fixed to a glass slide and stained with methylene blue. Selected areas of tissue were trimmed and ultrathin (silver) sections were cut using a Diatome ultra diamond knife and stained with uranyl acetate and lead citrate. Sections were examined under a Hitachi H7100 transmission electron microscope (Hitachi High-Tech Science Systems) at $75 \mathrm{kV}$, with images recorded digitally.

Bacteriology. Spleen and kidney of 6 fish were cultured aseptically and streaked on cytophaga, trypticase soy and blood agar (Difco Laboratories) and aerobically incubated at $\sim 20$ and $37^{\circ} \mathrm{C}$ for 48 to $72 \mathrm{~h}$. Samples from several fish were also incubated microaerophilically.

Botulism toxin. Sections of liver, kidney, heart and spleen from 8 fish were pooled (2 separate pools from each batch of fish examined) and submitted to the Animal Health Laboratory, University of Guelph, for mouse inoculation tests (Walker 1990).
Virus isolation and identification. Bluegill fry (BF-2), Chinook salmon embryo (CHSE-214), epithelioma papulosum cyprinid (EPC), koi fin (KF) and fathead minnow (FHM) cell lines maintained at the Regional Diagnostic Virology Services at the Atlantic Veterinary College were used. CHSE and KF cells were propagated at 15 to $16^{\circ} \mathrm{C}$, while room temperature $\left(\sim 20^{\circ} \mathrm{C}\right)$ was used for EPC, FHM and KF cell lines. All cell lines were incubated at $15^{\circ} \mathrm{C}$ following inoculation with tissue samples. The propagation medium consisted of Earle's minimum essential medium (EMEM) (Sigma), with glutamine and $10 \%$ foetal bovine serum (FBS) (Sigma or Hyclone). All caps of seeded tissue culture flasks were screwed tight before incubation at the specified temperature. Cells used for virus isolation were 1 or $2 \mathrm{~d}$ old and were grown in $25 \mathrm{~cm}^{2}$ tissue culture flasks (TCF).

Fish tissues were pressed and mashed in a cold block using the edge of a tip box before a $10 \%$ tissue homogenate in MEME with $500 \mathrm{IU}$ penicillin $\mathrm{ml}^{-1}$, $500 \mu \mathrm{g}$ streptomycin $\mathrm{ml}^{-1}$ and $1.25 \mu \mathrm{g}$ fungizone $\mathrm{ml}^{-1}$ (PSF) (Invitrogen) was prepared. This was centrifuged at $500 \times \mathrm{g}$ for $20 \mathrm{~min}$ at $4^{\circ} \mathrm{C}$ before the supernatant was collected and filtered at $0.45 \mu \mathrm{m}$. A 1:50 suspension was prepared using MEME with glutamine and PSF. Around $350 \mu \mathrm{l}$ of 1:50 filtrate dilution was inoculated in cell cultures after being washed 3 times with Dulbecco's phosphate-buffered saline (PBS) (Sigma) with magnesium chloride (Sigma). The inoculated cell cultures were incubated at 15 to $16^{\circ} \mathrm{C}$ for $1 \mathrm{~h}$ before maintenance medium, consisting of EMEM with $3 \%$ FBS and $100 \mathrm{IU}$ penicillin $\mathrm{ml}^{-1}, 100 \mu \mathrm{g}$ streptomycin $\mathrm{ml}^{-1}$ and $0.25 \mu \mathrm{g}$ fungizone $\mathrm{ml}^{-1}$, was added. Cultures were incubated again at 15 to $16^{\circ} \mathrm{C}$ and were examined after $1 \mathrm{~d}$ and every $7 \mathrm{~d}$ thereafter up to $28-30 \mathrm{~d}$; cultures that showed suspicious or developing cytopathic effects (CPE) were examined daily. The CPE was confirmed by a second passage using filtered clarified supernatant of the cell cultures showing CPE.

The virus was identified by TEM and by reverse transcriptase (RT) nested polymerase chain reaction (nPCR). Clarified cell culture homogenate that had CPE was filtered at $0.45 \mu \mathrm{m}$ and inoculated in 1 to $2 \mathrm{~d}$ old FHM cells in $75 \mathrm{~cm}^{2}$ TCF and grown as described. The cell monolayer was washed 3 times with PBS, before $1 \mathrm{ml}$ of PBS was added and the monolayer was scraped off. The cell suspension was suspended in an equal volume of $6 \%$ glutaraldehyde in $0.2 \mathrm{M}$ phosphate buffer for $1 \mathrm{~h}$ and centrifuged at $500 \times g$ for 15 min. Cells were post-fixed with $1 \%$ osmium tetroxide for $1 \mathrm{~h}$ at $20^{\circ} \mathrm{C}$ and centrifuged as before. Approximately 2 to $4 \%$ melted agarose was added to the pellet, and cells were resuspended in the solidifying agarose. The pellet was then processed for TEM.

Nested PCR was performed as described (Batts \& Winton 1998) with minor modifications. Briefly, extrac- 
tion of nucleic acid from cell culture supernatants (QuiAmp Viral RNA kit, Qiagen) was performed according to manufacturers' instructions. The first amplification was performed using $50 \mu \mathrm{l}$ of a reaction mixture utilising the rTth RT-PCR kit (Applied Biosystems) as follows: EzrTth DNA polymerase, $2.5 \mathrm{U}$; VHSVF1 and R1 primers, $0.4 \mu \mathrm{M}$ each; Mn, $2.5 \mu \mathrm{M}$; dNTPs, $200 \mu \mathrm{M} ; 5 \times$ PCR buffer, $10.0 \mu \mathrm{l}_{;} \mathrm{ddH}_{2} \mathrm{O}, 19.0 \mu \mathrm{l}$ and $5.0 \mu$ template. The second amplification was done using AmpliTaq Gold (Applied Biosystems) using $50 \mu \mathrm{l}$ of a mixture as follows: AmpliTaq Gold polymerase, $2.5 \mathrm{U}$; VHSVF2 and VHSVR2 primers, $0.4 \mu \mathrm{M}$ each; Mg, 2.0 mM; dNTPs, $200 \mu \mathrm{M}$; 10× PCR buffer, $5.0 \mu \mathrm{l}_{i} \mathrm{ddH}_{2} \mathrm{O}, 33.5 \mu \mathrm{l}$ and $2.0 \mu \mathrm{l}$ template.

VHSV ELISA. Isolate U13653-infected cell supernatants were tested with a VHSV antigen ELISA kit (VHSV Ag ELISA, Test-line) following the protocol supplied with the kit.

PCR and sequence analysis. A 468 base pair (bp) segment corresponding to nt 340 to 807 of the glycoprotein (G) gene was amplified by RT-PCR using the primer pair VHSVR1 5'-TTCTTTGGAGGGCAAACNATH-3' and VHSVF3 5'-GATCAGGTCCCCCARRTCNGT-3' (Stone et al. 1997, Dixon et al. 2003). Total RNA was extracted from $100 \mu \mathrm{l}$ of viral supernatant from infected FHM cells using the Trizol Reagent (Invitrogen) as described previously (Strømmen \& Stone 1997). Reverse transcription was performed at $37^{\circ} \mathrm{C}$ for $1 \mathrm{~h}$ in a $20 \mu \mathrm{l}$ volume consisting of $1 \times \mathrm{M}-\mathrm{MLV}$ RT reaction buffer (50 mM Tris [pH 8.3], $75 \mathrm{mM} \mathrm{KCL,}$ $10 \mathrm{mM}$ DTT, $3 \mathrm{mM} \mathrm{MgCl}_{2}$ ) containing $1.0 \mathrm{mM}$ dNTP mix, 100 pmol random hexamer primer, $20 \mathrm{U}$ M-MLV reverse transcriptase (Promega) and 1/10 of the total RNA extracted above. PCR was performed in a $50 \mu \mathrm{l}$ reaction volume of $1 \times$ Go Taq PCR buffer containing $2.5 \mathrm{mM} \mathrm{MgCl}_{2}, 1 \mathrm{mM}$ dNTPs mix, 50 pmol each of the VHSVR1 and VHSVF3 primers, 2.5 U of Go Taq polymerase (Promega) and $2.5 \mu \mathrm{RT}$ reaction mix. The reaction mix was overlaid with mineral oil and subjected to 40 temperature cycles of: $1 \mathrm{~min}$ at $95^{\circ} \mathrm{C}, 1 \mathrm{~min}$ at $55^{\circ} \mathrm{C}$ and $1 \mathrm{~min}$ at $72^{\circ} \mathrm{C}$, followed by a final extension step of $10 \mathrm{~min}$ at $72^{\circ} \mathrm{C}$. Amplified products were electrophoresed in a $2 \%(\mathrm{w} / \mathrm{v})$ agarose/TAE (40 mM Tris-acetate [pH 7.2], 1 mM EDTA) gel containing $1.0 \mu \mathrm{g}$ ethidium bromide $\mathrm{ml}^{-1}$, and visualised under UV irradiation. PCR products were purified using the Freeze $\quad N^{\prime}$ Squeeze DNA purification system (Anachem), and both DNA strands were sequenced using the VHSVR1 and VHSVF3 primers and the ABI PRISM dye terminator cycle sequencing system (Applied Biosystems). Sequencing reactions were analysed on an ABI 3100 genetic analyser using the Sequencher software (Gene Codes). Multiple alignments of a $360 \mathrm{bp}$ region (nt 361 to 720 ) were generated using ClustalW, and the phylogenetic analyses were performed using MEGA Version 3.1 (Kumar et al. 2004). The significance of the branching order was assessed by bootstrap resampling of 1000 replicates. The other sequences used in the analysis have been described previously (Stone et al. 1997, Nishizawa et al. 2002, Einer-Jensen et al. 2004).

\section{RESULTS}

\section{Outbreak pattern and mortality estimate}

The freshwater drum Aplodinotus grunniens dieoff was first reported the week of April 26, 2005, in Long Reach of the Bay of Quinte. Based on several reports, it is likely that the die-off began earlier, around April 22. At this time, the numbers of dead and dying drum increased rapidly from 100 to 200 at 2 locations, with similar numbers seen at $>6$ different locations. Dead and dying fish were observed along most shorelines of the Bay of Quinte from Trenton through to at least Glenora (Picton) with unconfirmed reports eastwards to Collins Bay near Kingston. The magnitude of the die-off was much smaller from Glenora eastwards, with several locations showing only dozens of fish. No dead fish were reported in the Outlet or Kingston basin. By the week of May 16, only 4 dying drum and 200 dead drum were observed for the entire area of the bay east of Belleville to Deseronto. Regardless, dying and dead drum were rarely seen for several weeks thereafter. Nevertheless, results from modelling suggested that between 20000 and just over 30000 drum were killed within a 35 to $40 \mathrm{~d}$ period during 2005 (Fig. 1). This equated to approximately 90 metric tonnes (based on an average, representative, observed weight of $3 \mathrm{~kg}$ for fish submitted for diagnostic examination). When index gill netting was performed during July through August 2005, the catch per net or relative abundance of this species increased slightly (B. Morrison pers. comm., Ontario Ministry of Natural Resources, 2006).

\section{Gross pathology}

Externally, all dead fish examined exhibited multifocal to regionally extensive hyperaemia and haemorrhages at the base of the pectoral and pelvic fins (Fig. 2a). In 5 fish, petechial and larger haemorrhagic patches extended from the ventral surface of the mouth to the anus. All fish exhibited mild to moderate bilateral exophthalmia and extensive haemorrhage of the iris, and 2 fish had unilateral hyphema. There was marked haemorrhage of the anus. No abnormalities 

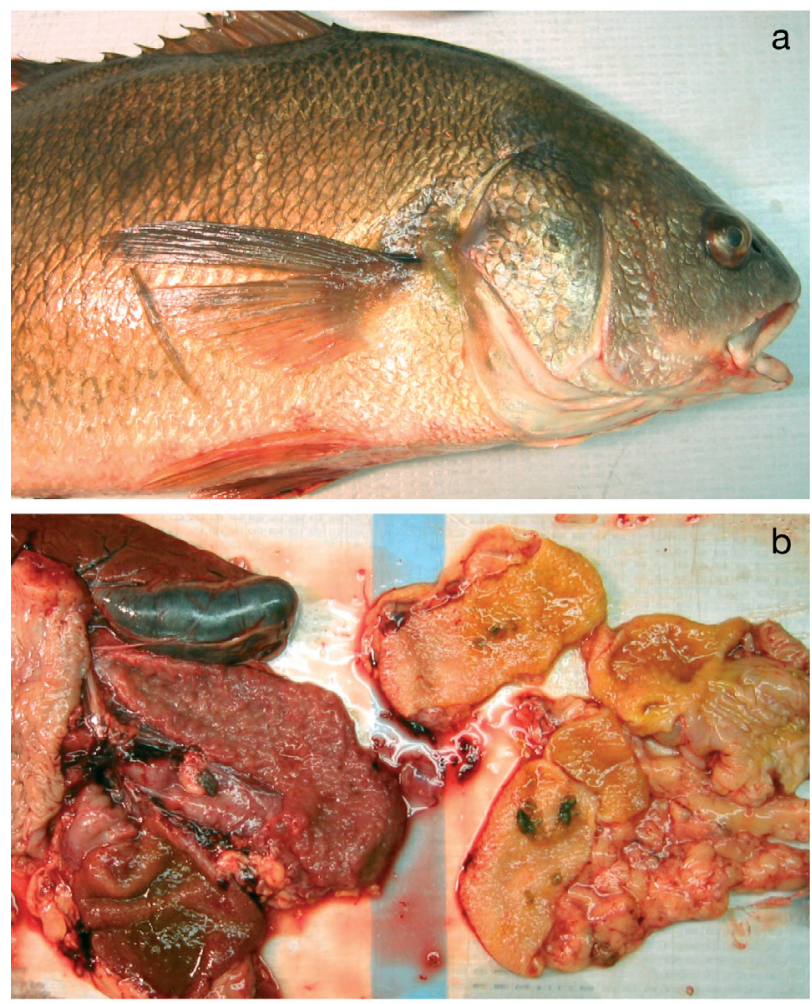

Fig. 2. (a) Aplodinotus grunniens. Gross appearance of a $3.2 \mathrm{~kg}$ drum with extensive haemorrhage and exophthalmia. (b) Diffuse segmental intestinal reddening with a roughened mucosa, a lesion that was present in the majority of the fish examined

were noted on wet mount examination of gill biopsies, skin scrapes, or feces. Internally, blood-tinged serosanguanous fluid was present in the abdomen of the majority of the fish, and there was extensive diffuse serosal and mucosal reddening of the proximal gastrointestinal tract (Fig. 2b). The epicardial surface of the heart often had a ground-glass appearance, and the meninges of the brain were hyperaemic. The spleens of 3 of the fish were moderately enlarged.

\section{Histopathology}

The tissues routinely examined included skin, muscle, brain, eye, gills, heart, anterior and posterior kidney, liver, exocrine pancreas, spleen, oesophagus, swim bladder, stomach, intestine and gonads. Tissues occasionally examined included inter-renal tissue, thyroid and endocrine pancreas. Both females and males were present. The most dramatic and consistent lesion that was seen to varying degrees in every fish examined was the vasculitis (arteritis and phlebitis) (Fig. 3) that was present in virtually every tissue to some extent. While there was a great degree of variation, the most distinctive presentation was that of a diffuse fibrinoid vasculitis characterised by a thin rim of eosinophilic hyaline amorphous material, and necrosis of endothelial cells. The pattern of inflammation varied from cell-poor to a marked expansion of the intimae and media by oedema and large numbers of macrophages, with fewer lymphocytes and other leukocytes. Perivascular infiltrates were most evident in the meninges, kidney and intestine. Sporadic necrotising and leukocyte-rich lesions that were oriented on blood vessels, but that extended into the surrounding parenchyma, were seen in most organs examined, including gills, hepatopancreas, swim bladder, dermis, skeletal muscle, stomach and oesophagus. The tissues in which the lesions were most dramatic were the heart, brain, intestine and, to a lesser extent, the kidney and spleen. Apart from vascularly oriented lesions in the spleen and kidney, the typical lesions were mild, often very minimal, multifocal necrosis of splenic ellipsoids and white pulp and renal interstitium.

The heart lesions ranged from mild to severe, with most fish having moderate to severe lesions, and the atrium was consistently the worst affected area. Peracute necrotising lesions were characterised by myofibril swelling and fragmentation, hypereosinophilia, nuclear karyorhexis (endothelium and myocytes) and few to no inflammatory cells, with variable but often marked oedema (Fig. 4). Swelling in some areas was severe enough to obliterate the intra-trabecular spaces of the heart. Less acute lesions consisted of necrosis, as described above, mixed with areas in which there was virtual replacement of myofibrils with swollen, intact-to-degenerate macrophages, with

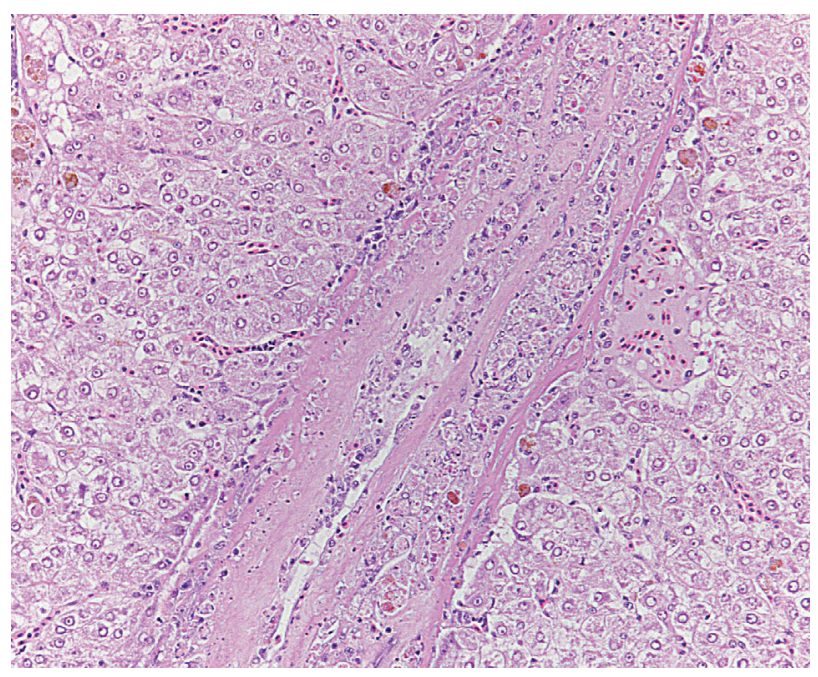

Fig. 3. Aplodinotus grunniens. Severe vasculitis. A hepatic blood vessel with fibrinoid necrosis and with all layers markedly expanded by oedema and debris- and pigmentfilled macrophages. The endothelium is discontinuous with luminal fibrin and cellular debris. H\&E. 160x 
cytoplasm stuffed with golden-brown pigment, marked oedema and eosinophilic flocculent debris (Fig. 5). Apparently older lesions also had an, often florid, endo- and epicarditis, with a distinctive marked hypertrophy and hyperplasia of endo- and epicardial cells. This was in combination with a marked influx of macrophages with fewer smaller leukocytes (neutrophils) mixed with fibrin, necrotic debris and pericardial haemorrhage. Multifocal to confluent areas of the atrium in 1 fish were undergoing sequestration with zones of macrophages and early fibroplasia bordering more normal tissue. In several fish, $>50 \%$ of the atrium was necrotic.

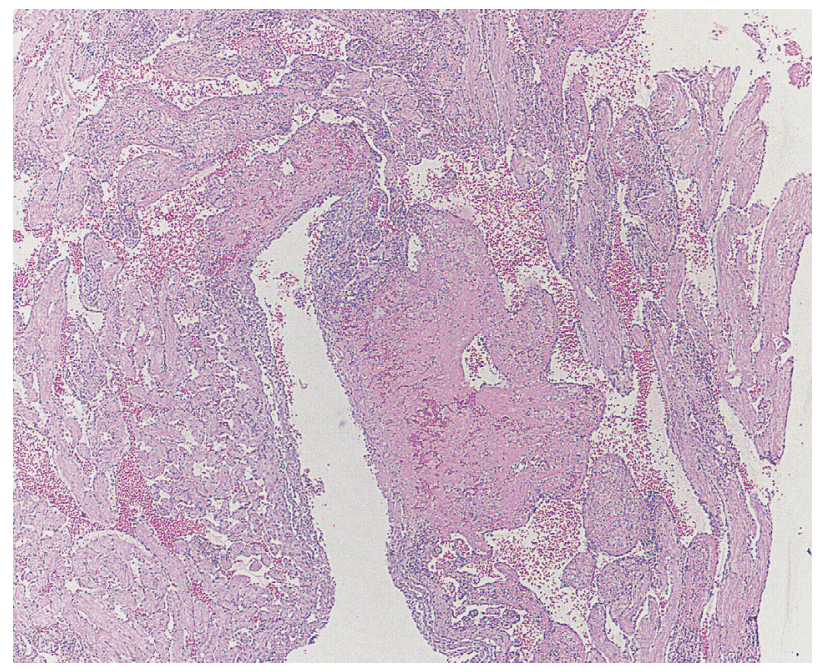

Fig. 4. Aplodinotus grunniens. Widespread multifocal necrosis of atrial myocardium with hypereosinophilia and expansion of trabeculae as well as a diffuse endocarditis, mild hyperplasia of endocardium and a histocytic myocarditis. H\&E. 16×

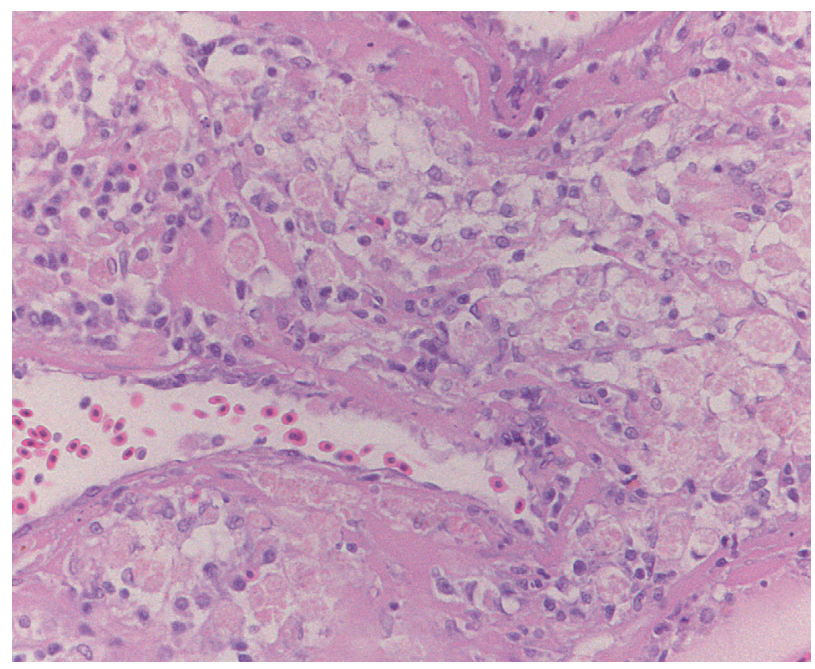

Fig. 5. Aplodinotus grunniens. Myocardial trabeculae that match the description given for the hepatic blood vessel in Fig. 3. H\&E. 200x
The meninges were diffusely thickened up to 30-fold above normal, and the meningeal venules and arterioles were undergoing fibrinoid vasculitis with an efflux of red blood cells, protein and a large population of intact and necrotic lymphocytes and macrophages with fewer plasma cells (Fig. 6). Similar to the heart, very large macrophages were laden with cellular debris and were present both in the vessel walls and expanded meninges. The adjacent neuropil was diffusely oedematous, with limited neuronal degeneration and necrosis. The inflammatory cells did not extend extensively into the neuropil, but there were multiple small foci in the higher brain, medulla and spinal cord, consisting of glial cells and a few macrophages and lymphocytes. The cranial nerves, in contrast, were often heavily infiltrated with lymphocytes and fewer macrophages.

The proximal intestine was consistently affected. Within basal aspects of the intestinal folds, sections of necrotic epithelium were replaced by a variably tenuous layer of thinned, basophilic epithelial cells. Many areas were incompletely re-epithelialised. The lamina propria immediately surrounding these areas was moderately to densely infiltrated with macrophages, and fewer lymphocytes and other leukocytes (Fig. 7), and these cells were often present diffusely in other areas of the lamina propria. The remainder of the intestinal epithelium was largely unaffected.

All well-vascularised structures in the eye were usually affected to some degree. In particular, the rete, choroid and iris, particularly the latter, were expanded by oedema and large numbers of leukocytes with haemorrhage from inflamed vessels. The anterior chamber was often filled with red blood cells, proteinaceous fluid and numerous leukocytes (Fig. 8).

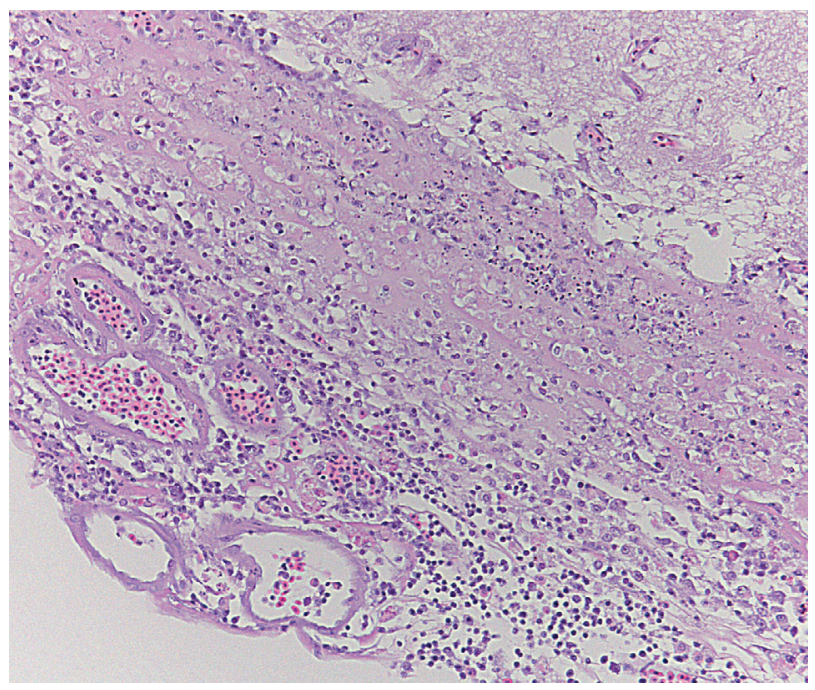

Fig. 6. Aplodinotus grunniens. Florid diffuse meninigitis and several dilated arterioles with fibrinoid change and necrosis of endothelium and of smooth muscle. H\&E. 160x 


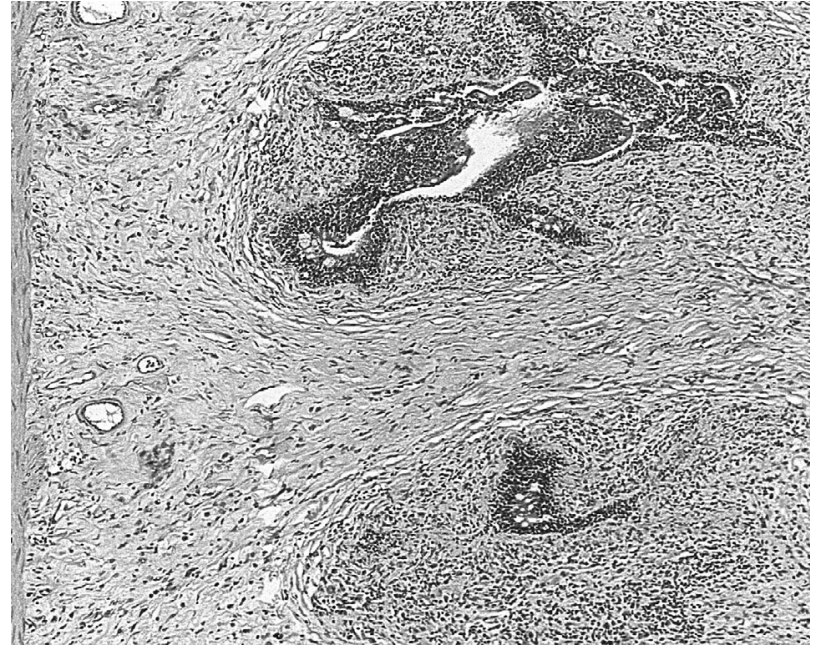

Fig. 7. Aplodinotus grunniens. Necrotizing enteritis with epithelial ulceration and regeneration (thinning of remaining epithelium). Adjacent lamina propria is infiltrated with moderate numbers of leukocytes. H\&E. 40x

Sporadic lesions that were seen in 1 or, at most, 2 fish and were considered to be incidental included: numerous intra-glomerular and intra-tubular pre-spore myxosporeans, focal renal interstitial microsporean xenoma/cysts, intra-biliary larval cestodes, intestinal luminal trematodes ( 2 fish). Lesions that were seen in the majority of the fish examined, but were also considered to be incidental, based on tissue reaction, distribution, etc., included: small numbers of multifocal $\sim 1 \times 2 \mathrm{~cm}$ dermal proliferative nodules and multifocal renal interstitial, splenic and hepatopancreatic granulomas. The former are consistent with melanistic chro-

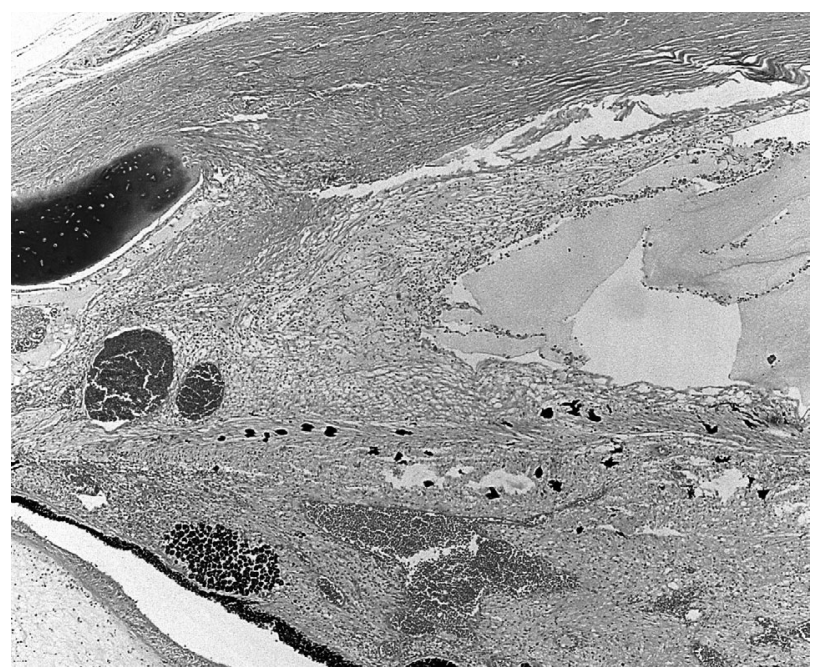

Fig. 8. Aplodinotus grunniens. The iris is expanded by inflammation and haemorrhage and the anterior chamber is filled with eosinophilic fluid, red blood cells and inflammatory cells. H\&E. 40x matophoromas or melanomas. The latter were typical of those associated with migration of metazoan parasites (well formed, variably sized $~ 100$ to $400 \mu \mathrm{m}$, thin outer rim of concentric fibrocytes surrounding a small number of macrophages with copious central eosinophilic amorphous debris), although no metazoan structures remained. These granulomas did not contain acid-fast organisms. Special stains did not reveal any organisms save those already mentioned above.

\section{Transmission electron microscopy}

Moderate numbers of bullet-shaped viral particles were present extracellularly in multiple sections of affected heart. Marked disruption of cells and cellular debris was also present, as well as moderate autolytic changes (Fig. 9).

\section{Bacteriology and botulinum toxin}

No bacterial growth was noted from any of the fish on any of the media used. Mouse inoculation assays for botulinum toxin were negative.

\section{Virus isolation and identification}

CPE was detected in inoculated FHM cells after 2 to $6 \mathrm{~d}$ and in inoculated BF-2 and KF cells after 6 to $9 \mathrm{~d}$.

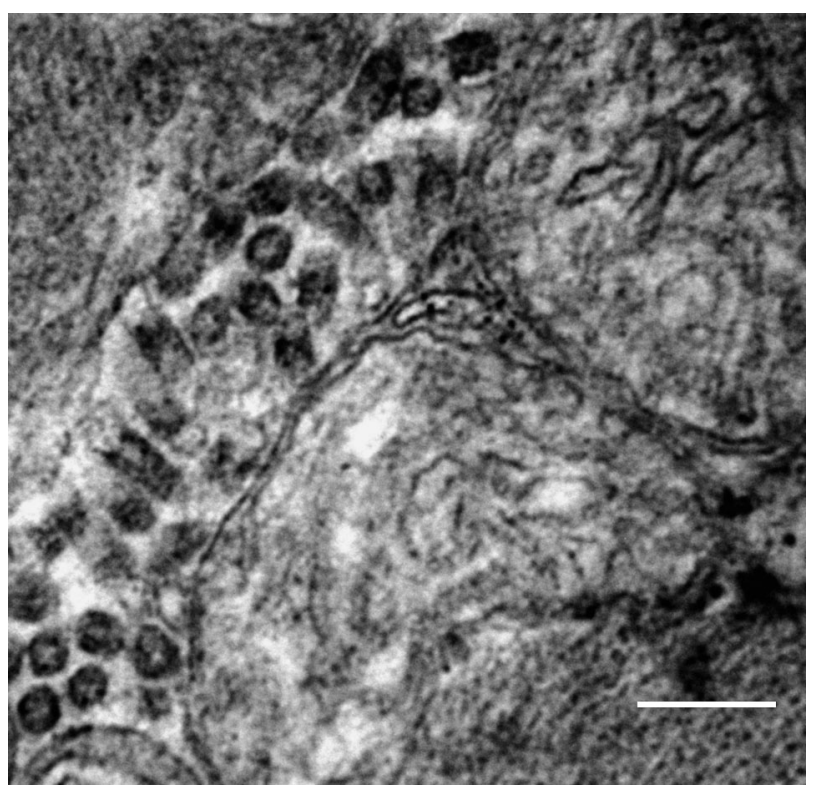

Fig. 9. Aplodinotus grunniens. Numerous bullet-shaped viral particles were visualized by transmission electron microscopy of glutaraldehyde-fixed heart tissue from affected freshwater drum. Scale bar $=200 \mathrm{~nm}$ 
Typically, CPE was noted by the second day and affected the whole culture by Day 6. CPE was detected consistently on second and subsequent passages within 24 to $48 \mathrm{~h}$ in FHM cells, while CPE was detected between 3 and $9 \mathrm{~d}$ on second passage in BF- 2 cells. No CPE was detected in CHSE and EPC cell lines after first and second passages. TEM of inoculated FHM cells demonstrated numerous bullet-shaped $\sim 165 \times$ $60 \mathrm{~nm}$ viral particles budding from plasma membranes and aggregated inside cellular vesicles (Fig. 10). The expected PCR products, a $950 \mathrm{bp}$ from the first round and $558 \mathrm{bp}$ for the nested product (Batts \& Winton 1998), for VHSV were obtained (not shown).

\section{VHSV ELISA}

The isolate from drum, U13653 (CEFAS stain number), and both reference marine and freshwater isolates of VHSV, in addition to the positive supplied with the kit had absorbance values (optical density at $450 \mathrm{~nm}$; average of duplicate wells) at least 3 -fold greater $(0.844,0.796,0.790$ and 0.699 , respectively) than that of the negative control $(0.159)$.

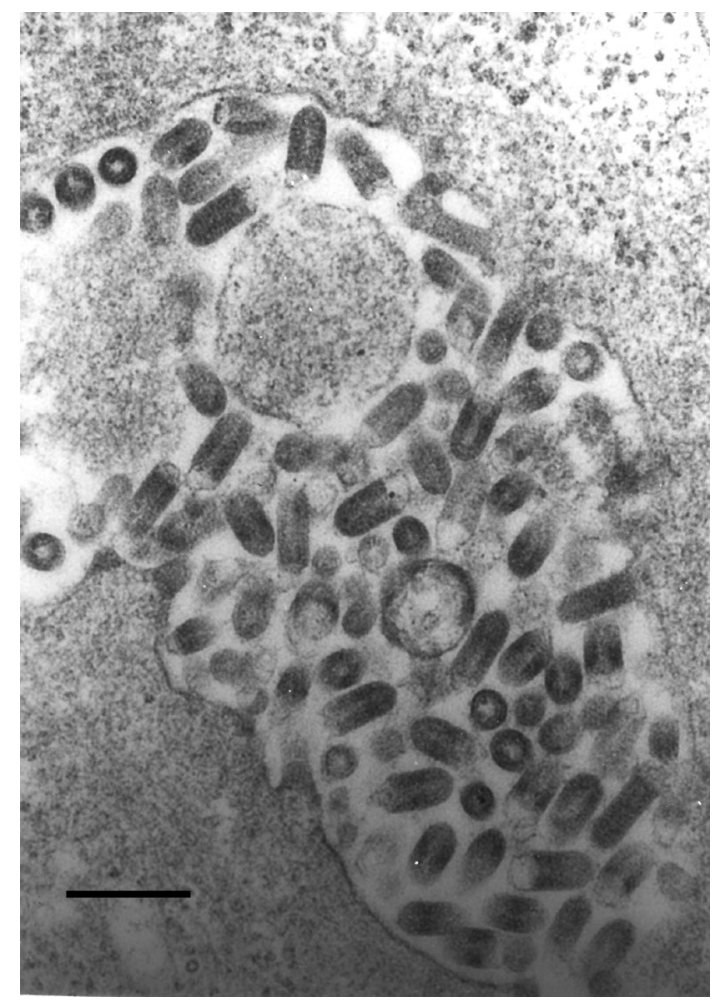

Fig. 10. Transmission electron microscopy of the fathead minnow cell line inoculated with VHSV, $24 \mathrm{~h}$ post-infection. Numerous bullet-shaped particles in a cellular vesicle. Scale bar $=200 \mathrm{~nm}$

\section{PCR and sequence analysis}

An appropriately sized product (468 bp) was generated when using the VHSV-specific primer set VHSVR1 and VHSVF3 (Dixon et al. 2003) and RNA extracted from the U13653 culture supernatant. No product was generated with the extraction control (Fig. 11). In a multiple alignment of $360 \mathrm{bp}$ partial G-gene sequences (nt 360 to 720) taken from published data (Stone et al. 1997, Nishizawa et al. 2002, Einer-Jensen et al. 2004), the U13653 G-gene sequence was shown to have 10 to 13 nucleotide differences (96.4 to $97.2 \%$ nucleotide identity) when compared to the strains of NA VHSV (Fig. 12) and $>52$ nucleotide differences $(<82.6 \%$ nucleotide identity) when compared to the European Genogroup I viruses. Neighbour-joining distance analysis (Fig. 13) assigned U13653 to the same lineage as the NA and Japanese isolates (Genogroup IV).

\section{DISCUSSION}

This paper has reported an outbreak of VHSV in freshwater drum Aplodinotus grunniens in Lake Ontario. VHSV was isolated and identified by TEM, nested RT-PCR using published primers and by a VHSV ELISA kit. Initial phylogenetic analysis assigned the virus isolate (U13653) to the NA genogroup; moreover, the analysis suggests that this isolate likely represents a distinct subgroup of NA VHSV.

As outbreaks in the Great Lakes continue, the number of affected species identified will presumably expand.

The species range of VHSV is wide (Skall et al. 2005), but the impact on the populations of individual species has yet to be determined. The number of drum

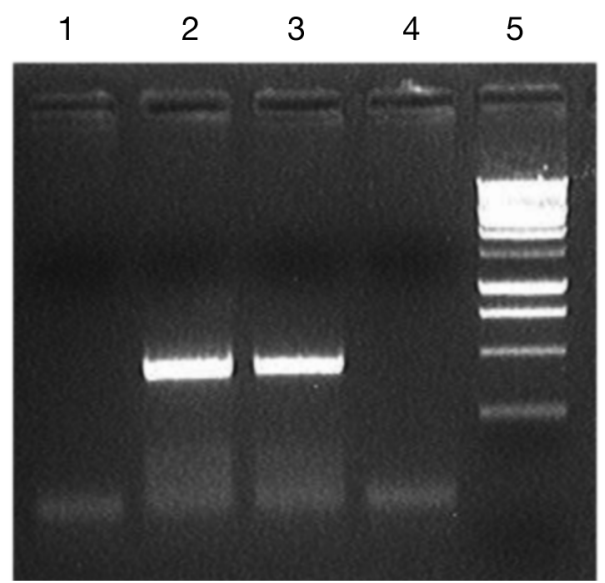

Fig. 11. Generation of a $468 \mathrm{bp}, \mathrm{VHSV}$-specific amplicon for the Lake Ontario (U13653) isolate. Lanes 1 and 4, extraction controls; lanes 2 and 3, isolate; lane 5, $1 \mathrm{~kb}$ DNA marker 


\begin{tabular}{|c|c|c|c|c|c|c|}
\hline & 370 & 380 & 390 & 400 & 410 & 420 \\
\hline U13653 & GAAAAGACCA & TCCTGGAAGC & AAAGCTGTCC & CGTCAAGAGG & CCACCAATGA & GGCCGGCAAG \\
\hline akah & . .А. . & ...G. & $\ldots$ & $\ldots$ & $\ldots \ldots \ldots$ & $\ldots \ldots \ldots$ \\
\hline AK-93 & ......... & ......G. & $\ldots \ldots \ldots$ & $\ldots \ldots \ldots$ & $\ldots \ldots \ldots$ & $\ldots \ldots \ldots$ \\
\hline AK-93-1 & $\ldots$. А. & .......G. & $\ldots \ldots \ldots$ & $\ldots \ldots \ldots$ & $\ldots \ldots \ldots$ A. & $\ldots \ldots \ldots$ \\
\hline EB-7 & $\ldots$ А... & .....G. . & $\ldots$ & $\cdots$ & $\cdots \cdots \cdots$ & $\cdots$ \\
\hline$B C-93$ & $\ldots$ А... & ......G. & $\ldots$ & $\cdots$ & $\ldots \ldots$ & . \\
\hline Elok & ...А. А. & ......G. & $\ldots$ & & $\cdots$ & $\ldots$ \\
\hline NA -5 & $\ldots$. А... & ......G. & $\ldots$ & $\ldots \ldots \ldots$ & $\ldots \ldots \ldots$ & $\ldots \ldots \ldots$ \\
\hline NA- 6 & $\ldots$. А... & ......G. & $\ldots$ & $\ldots \ldots \ldots$ & $\ldots \ldots \ldots$ & $\ldots \ldots \ldots$ \\
\hline NA- 7 & $\ldots$. А... & .......G. & $\ldots \ldots \ldots$ & $\ldots \ldots \ldots$ & $\ldots \ldots \ldots$ & $\cdots \cdots$ \\
\hline NA -8 & $\ldots$. & ....G. & $\ldots$ & & $\ldots \ldots \ldots$ & $\ldots \ldots \ldots$ \\
\hline Obama 25 & $\ldots$. А... & ......G. & $\ldots \ldots \ldots$ & $\ldots \ldots \ldots$ & $\ldots$ т..... & $\ldots$ т.... \\
\hline 814 & $\ldots \ldots \ldots$ & $\ldots \ldots \ldots$ & $\ldots$. . . . T & ....G.... & $\ldots$. $\ldots$ & $\ldots$ AA $\ldots$. \\
\hline $\mathrm{H} 17 / 5$ & $\ldots \ldots \ldots$ & $\ldots \ldots \ldots$ & $\ldots \mathrm{AT} \ldots \mathrm{T}$ & ....G.... & .G.A..... & $\ldots \mathrm{AA} \ldots$. \\
\hline $\mathrm{H} 19 / 1$ & $\ldots \ldots \ldots$ & $\ldots \ldots \ldots$ & $\ldots$. АТ ... & ....G.... & .G.A..... & $\ldots \mathrm{AA} \ldots$. \\
\hline UK-MLA98 / 6PT11 & ...А. А. & $\ldots \ldots \ldots$ & $\ldots$. АТ ... Т & ....G.... & .G.A..... & $\ldots$ AA $\ldots$. \\
\hline SE-SVA14 & .G...A. & .T...G. & G..AT ... T & ....G.... & ...А. С. & $\ldots$ AA..... \\
\hline NO-A16368 & $\ldots \ldots \ldots$ & . .T....G. & G. .АT... T & ....G.... & ...A. . . & $\ldots$ AA $\ldots$. \\
\hline SE-SVA1033 & .G....A. & .T....G. & G. . AT .... T & ....G... & ...А. .С. & $\ldots$ AA $\ldots$. \\
\hline TR-Bs13/15H & .G...... & .T....G. & G..AT $\ldots$ T & ....G.... & $\ldots$ А.... & $\ldots$ AA $\ldots$. \\
\hline $02-84$ & $\ldots \ldots \ldots$ & .T....G. & G..A...T & $\ldots$. G.... & ....AG.C. & $\ldots$ AA $\ldots$ \\
\hline KRRV_9601 & .G...A. & . .T....G. & G. . AT ... T & ....G... & ...А.С. & $\ldots$ AA $\ldots$ \\
\hline F1 & $\ldots \ldots \ldots$ & . .T....G. & G.AT...T & ....G.... & ....GG.C. & $\ldots \mathrm{AA} \ldots \ldots$ \\
\hline 7321 & $\ldots \ldots \ldots$ & . .T....G. & G.A....T & ....G.... & ....AG.C. & $\ldots$ AA $\ldots$. \\
\hline Klapmolle & $\ldots \ldots \ldots$ & . .T....G. & G.GA...T & ....G.... & ...А. .С. & $\ldots$ AA $\ldots$. \\
\hline $83-53$ & $\ldots \ldots \ldots$ & .T...G. & G. . AT ... T & ....G.... & ...A. . . & $\ldots$ AA..... \\
\hline 670 & $\ldots \ldots \ldots$ & .T....G. & G.GAT ... . T & ....G.... & ...A. . С. & $\ldots$ AA $\ldots$. \\
\hline $23-75$ & $\ldots \ldots \ldots$ & .T....G. & G.A. . . . T & ....G.... & ...A. .С. & $\ldots$ RA..... \\
\hline Rindsholm & $\ldots \ldots \ldots$ & .T....G. & G..A...T & ....G.... & ...A.AG.C. & $\ldots$ AA $\ldots$. \\
\hline 609 & $\ldots \ldots \ldots$ & .T....G. & G. . AT .... T & $\ldots$ G.... & ....AG.C. & $\ldots$ AA. . . \\
\hline 448 & $\cdots$ & . .T....G. & G.A...T & ....G.... & ....AG.C. & $\ldots$ AA $\ldots$ \\
\hline Grasmuck & $\ldots \ldots \ldots$ & .T....G. & G.A...T & ....G.... & ...AG.C. & $\ldots \mathrm{AA} \ldots \ldots$ \\
\hline 957 & $\ldots \ldots \ldots$ & . .T....G. & G.A....T & ....G.... & ...AG.C. & $\ldots$ AA $\ldots$. \\
\hline \multirow[t]{2}{*}{$17-91$} & $\ldots \ldots \ldots$ & .T....G. & G.A. . . T & ....G.... & ....AG.C. & $\ldots$ АA $\ldots$. \\
\hline & 490 & 500 & 510 & 520 & 530 & 540 \\
\hline U13653 & AAGGACATAA & СССАСТАТТА & CAAGACCCCA & AAGACAGTGT & CCATCGATCT & CTACAGTAGA \\
\hline Makah & $\ldots \ldots \ldots$ & $\cdots \cdots \cdots$ & $\ldots \ldots \ldots$ & $\ldots$ т..... & $\ldots$ т.... & $\ldots \ldots \ldots$ \\
\hline $\mathrm{AK}-93$ & $\ldots \ldots \ldots \ldots$ & $\ldots \ldots \ldots$ & $\ldots \ldots \ldots$ & $\ldots \ldots \ldots$ & $\ldots$ т.... & $\ldots \ldots \ldots$ \\
\hline AK-93-1 & $\cdots \cdots \cdots$ & $\cdots \ldots \ldots$ & $\ldots \ldots \ldots$ & $\ldots \ldots \ldots$ & $\ldots$ т.... & $\ldots \ldots \ldots$ \\
\hline EB-7 & $\cdots \ldots \ldots$ & $\ldots \ldots \ldots$ & $\ldots \ldots \ldots$ & $\ldots \ldots \ldots$ & $\ldots$ т.... & $\ldots \ldots \ldots$ \\
\hline BC- 93 & $\ldots \ldots \ldots$ & $\ldots \ldots \ldots$ & $\ldots \ldots$ & $\ldots \ldots \ldots$ & $\ldots$ т.... & $\ldots \ldots \ldots$ \\
\hline Elok & $\ldots \ldots \ldots$ & $\ldots \ldots \ldots$ & $\ldots \ldots \ldots$ & $\ldots \ldots \ldots$ & $\ldots$ т.... & $\ldots \ldots \ldots$ \\
\hline NA -5 & $\cdots \cdots \cdots$ & $\ldots \ldots \ldots$ & $\ldots \ldots \ldots$ & $\ldots \ldots \ldots$ & $\ldots$. $\ldots$ & $\ldots \ldots \ldots$ \\
\hline NA -6 & $\ldots \ldots \ldots$ & & $\cdots$ & $\cdots \cdots$ & $\ldots$ т.... & $\cdots \cdots$ \\
\hline NA- 7 & $\cdots \ldots \ldots \ldots$ & $\ldots$ & $\ldots \ldots \ldots$ & $\ldots \ldots \ldots$ & $\ldots$ т.... & $\cdots \cdots$ \\
\hline NA- 8 & $\ldots \ldots \ldots$ & $\cdots \cdots$ & $\ldots \ldots$ & $\cdots \cdots$ & ……. & $\cdots \cdots$ \\
\hline Obama 25 & $\ldots \ldots \ldots$ & $\cdots$ & $\cdots$ & $\ldots \ldots \ldots$ & $\ldots$ т.... & $\ldots \ldots \ldots$ \\
\hline 814 & .... т... & . Т... & т....... & .А.... С. & .TG.G.... & ....C.G \\
\hline $\mathrm{H} 17 / 5$ & …… & т....... & т........ & .А.... C. & .TG.G.... & ....C.G \\
\hline $\mathrm{H} 19 / 1$ & ...т. & . т.... & т........ & .GA..... & .TG.G... & .....C.G \\
\hline UK-MLA98 / 6PT11 & ...т. т... & т...... & T........ & .А.... С. & .TG.G.... & ....C.G \\
\hline SE-SVA14 & $\cdots \cdots \cdots$ & т. $\ldots \ldots$ & $\ldots \ldots \ldots$ & .A. . . A & .GG.G.... & $\ldots \ldots \mathrm{C} . \mathrm{G}$ \\
\hline NO-A16368 & $\ldots \ldots \ldots$ & т...... & $\ldots \ldots$ & .А. . . A. & .GG.G.... & ....C. .G \\
\hline SE-SVA1033 & $\ldots \ldots \ldots \ldots$ & т. $\ldots \ldots$ & $\ldots \ldots$ & .А. . . A. & .GG.G.... & ....C.G \\
\hline TR-Bs13/15H & $\ldots \ldots \ldots c$. & . . . Т.... & $\ldots \ldots \ldots$ & .A. . . C. & .AG.G.... & ....C.G \\
\hline $02-84$ & $\ldots \ldots \ldots$ & т....... & $\ldots \ldots \ldots$ & .А. . . A & .GG.G.... & ....C.G \\
\hline KRRV_9601 & $\ldots \ldots \ldots$ & т...... & $\ldots \ldots$ & .А. . . A & .GG.G.... & ....C.G \\
\hline F1 & $\ldots \ldots \ldots$ & т....... & $\ldots \ldots \ldots$ & .A..... & .GG.G.... & ....C.G \\
\hline 7321 & $\ldots \ldots \ldots$ & Т..... & & .А. . . A. & .GG.G.... & ..C.G \\
\hline Klapmolle & $\ldots \ldots \ldots$ & . T. & & .A. . . A & .GG.G.... & ...... с.. \\
\hline $83-53$ & ...... & . T. & $\cdots$ & . А. . . A. & .GG.G.... & ....C.G \\
\hline 670 & $\cdots \cdots$ & . Т... & $\cdots$ & .А. . . A. & .GG.G.... & ....... с. \\
\hline $23-75$ & $\ldots \ldots \ldots$ & т...... & $\ldots \ldots$ & .A..... & .GG.G.... & ........ \\
\hline Rindsholm & & т...... & $\ldots \ldots$ & .A. . . A & .GG.G.... & .....C.G \\
\hline 609 & & т...... & $\ldots \ldots$ & .А. . . A & .GG.G.... & ....C.G \\
\hline 448 & $\ldots \ldots \ldots$ & т...... & $\ldots \ldots \ldots$ & .А. . . A & .GG.G.... & ....C.G \\
\hline Grasmuck & $\ldots \ldots \ldots$ & т...... & $\ldots \ldots \ldots$ & .A..... & .GG.G.... & ....C.G \\
\hline of & $\ldots \ldots \ldots$ & т....... & $\ldots \ldots \ldots \ldots$ & .A..... & .GG.G.... & ...C. .G \\
\hline & & & & A. . A & . GG.G. & . C. .G \\
\hline
\end{tabular}
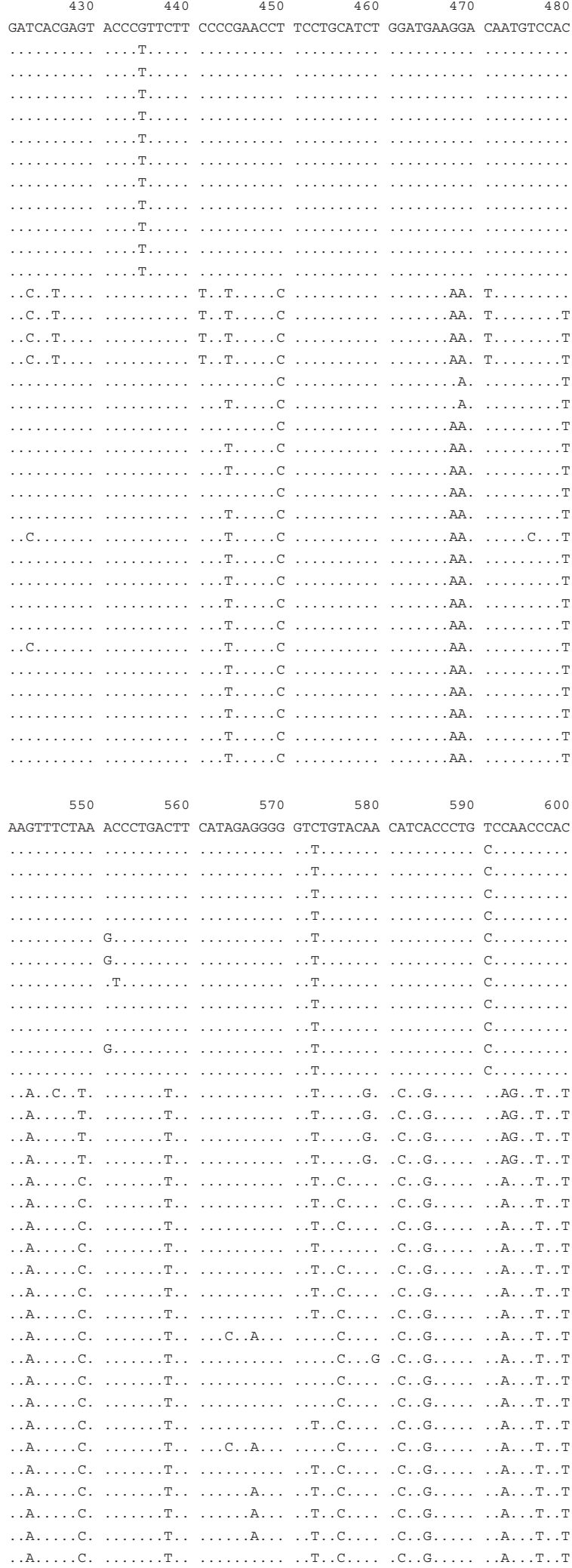

(Fig. 12 continued on next page)

Fig. 12. Alignment of nucleotides 361-720 of the glycoprotein gene of isolate U13653 with the sequences for 33 VHSV isolates from Europe, Japan and America. Dots indicate the positions of sequence identity compared to U13653 


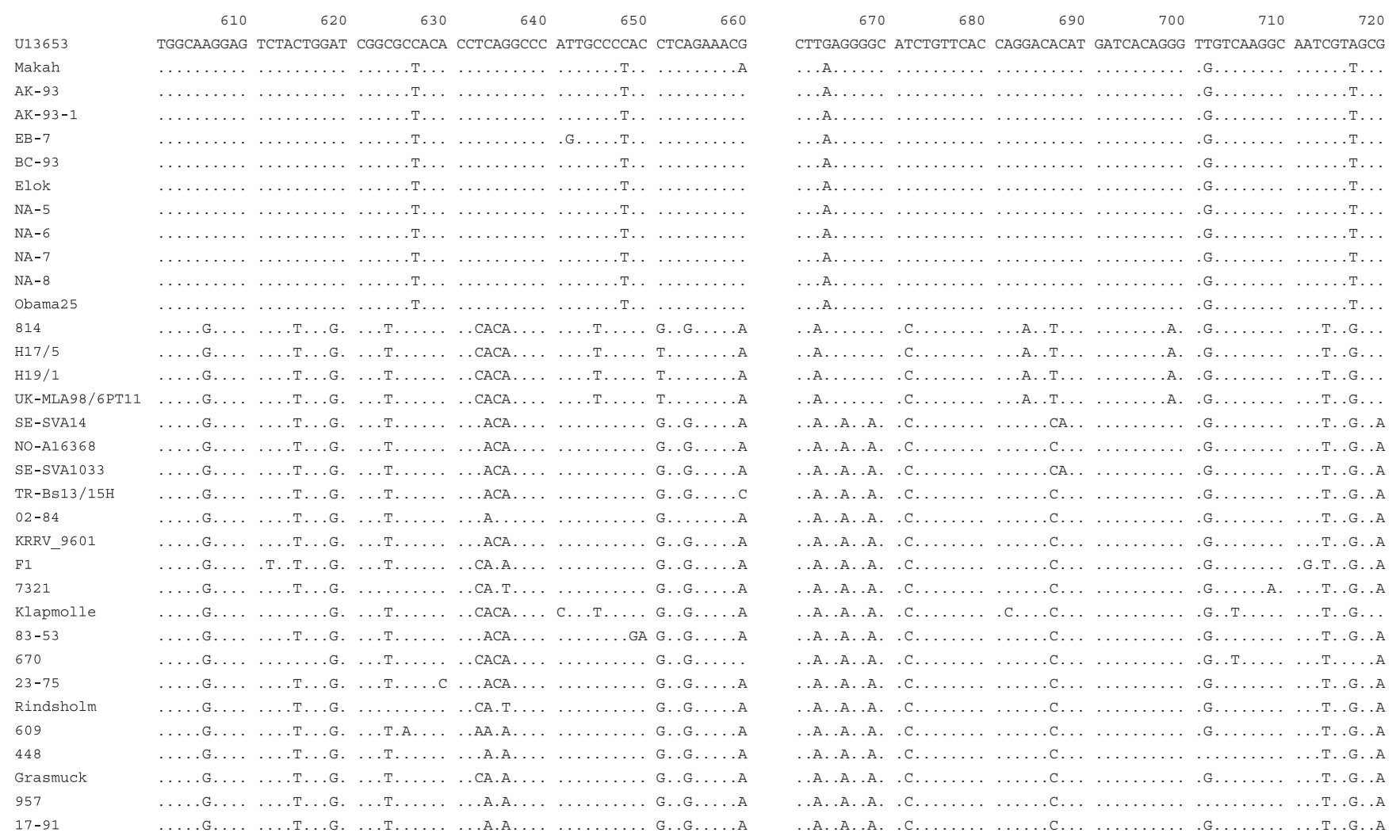

Fig. 12 (continued)

killed in the present outbreak was large enough to attract attention, but perhaps not large enough to dramatically impact the local population, as no reductions in drum were noted in subsequent surveys. Alternatively, drum may have moved into the bay after the mortality event dissipated. Additional mortality events in several species of fish, including drum, occurred in several locations in Lakes Erie, Ontario, and St. Clair in the spring of 2006. Both muskellunge (Elsayed et al. 2006) and round goby (P. Bowser, Cornell University, pers. comm.) have now been demonstrated to be infected by VHSV. A VHSV-specific PCR product has subsequently been obtained from both muskellunge and round goby that died during the 2005 Bay of Quinte mortality event (L. Al-Hussinee unpubl. data).

The lesions seen in drum are more similar to the patterns described in both marine fish from the mortality events in the Pacific (Marty et al. 1998) and those lesions described in turbot Scophthalmus maximus (Brudeseth et al. 2005), in that tissue other than the spleen and kidney appear to be the primary targets. Since a major target of VHSV is the vasculature (and presumably the endothelium), virtually every organ can be affected to some degree. Unlike salmonids, the most dramatically affected tissues in the drum were not the spleen and renal interstitium, but the heart and meningial vessels and, to a lesser extent, the proximal intestine. The character of these lesions was subacute with extensive hyperplasia of the endo- and epicardium, sequestration of portions of the atrium, and re-epithelialisation of the intestine, all suggesting that these larger drum survived for many days with fulminating lesions similar to the course of disease in experimentally infected turbot (Brudeseth et al. 2005).

As described, the gross lesions noted in the drum affected during the 2005 outbreak were dramatic. Smaller drum necropsied from Lake St. Clair that died in the spring of 2006 and were confirmed to be infected with VHSV had very subtle gross lesions. Without the heightened interest generated by the 2005 mortality event these fish would likely not have been examined at all. These drum had similar but less dramatic histological lesions, in which a less severe vasculitis and mild myocarditis were most characteristic. The fact that some groups of freshwater drum can die acutely with few lesions, while others survive for extended periods and develop extensive lesions, suggests the involvement of either an age-dependant phenomenon or physiological and/or environmental factors yet to be understood. The temperature of the water in Lake St. Clair in 2006 (smaller fish) was approximately $15^{\circ} \mathrm{C}$, 


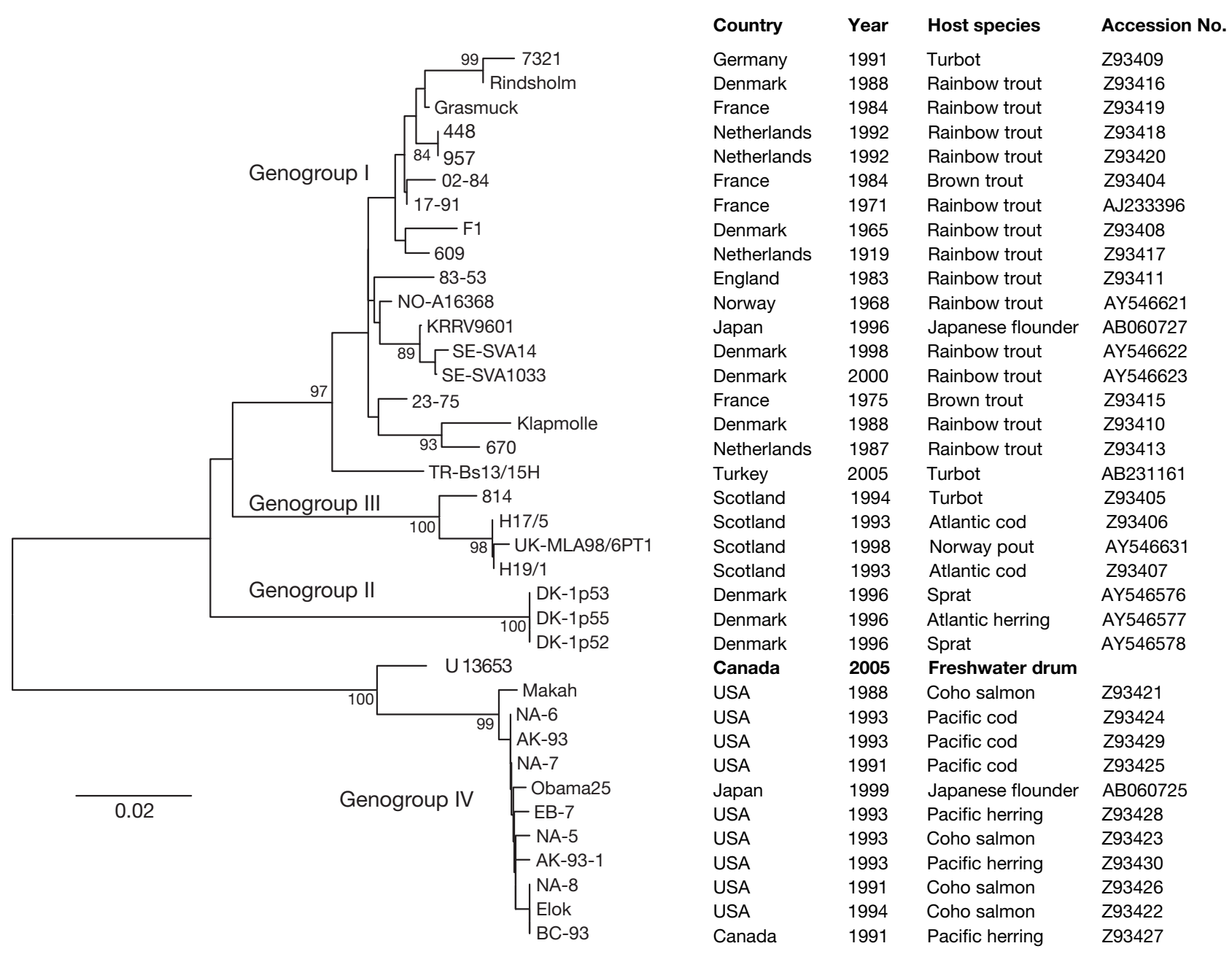

Fig. 13. Neighbour-joining distance tree based on a 360 bp partial glycoprotein sequence (nt 360-720) for a range of VHSV isolates from Europe, America and Japan, showing the corresponding country of origin, year of isolation, host fish species and accession numbers. The tree was generated using MEGA version 3.1 (Kumar et al. 2004). Analysis was done on 1000 bootstrapped data sets and values of $>70 \%$ are shown on the tree. Scale bar represents substitutions per nucleotide site

while, during the 2005 outbreak in the Bay of Quinte (larger fish), it ranged between 8 and $14^{\circ} \mathrm{C}$. Water temperature fluctuations during the spring up to $5-6^{\circ} \mathrm{C}$ over the course of a few days in both bodies of water are very common.

Spring mortality events associated with seasonal water mixing and dramatic temperature alterations are not uncommon and are rarely investigated. They occur at a similar time to the appearance of autolysed fish that died much earlier in the winter. Fish die-offs can occur over much of the year due to wind-driven temperature inversion, but also due to botulism toxicity. The latter are increasing in frequency in the lower Great Lakes and occur in the spring and summer/fall. VHSV-induced mortality has not yet been documented in the fall; however, it may occur when temperatures drop back into a range that is permissive for viral repli- cation. There is now evidence from archival samples that VHSV has been present in muskellunge Esox masquinongy in Lake St. Clair since at least 2003 (Elsayed et al. 2006). Muskellunge are uncommon in the Bay of Quinte, and a marked increase in mortality at that location has not been noted. Muskellunge, unlike drum, are top predators and are the subject of intense interest from biologists and anglers. In years previous to $2005,<5$ dead adult muskellunge were noted annually in the St. Lawrence mouth area. In contrast, during the spring of 2005, 75 dead muskellunge were observed and/or collected within the St. Lawrence River and 1000 Islands area, which are contiguous with the Bay of Quinte (J. Cassellman, Queens University, pers. comm.). Most of these specimens were autolysed, none were preserved for histology and only a few were frozen for RT-PCR (virus isolation was 
attempted but unsuccessful). Spring die-offs of muskellunge have also occurred in Lake St. Clair (upstream of Lake Ontario) for the past 4 yr. Outbreaks of VHSV have been associated with environmental stressors (reviewed by Skall et al. 2005), including netting, predation, poor nutrition, co-infection and low temperature. A substantial environmental stress in the case of either the drum or muskellunge has not been apparent.

VHSV Genogroup IV have been isolated from returning chinook and coho salmon without clinical signs (Brunson et al. 1989, Hopper 1989; reviewed by Meyers \& Winton 1995), with the resultant culling of hatchery salmonids. The presence of VHSV Genogroup IV on the Pacific coast of Canada and the United States has been repeatedly demonstrated (Meyers \& Winton 1995), and the virus has been isolated in late winter and spring from farmed Atlantic salmon Salmo salar in British Columbia with no or low mortality (G. Traxler, Pacific Biological Station, Naniamo, British Columbia, pers. comm.). However, a substantial health impact on salmonids in the last $15 \mathrm{yr}$ has yet to be demonstrated. Infection studies in rainbow trout Oncohynchus mykiss and Pacific and Atlantic salmon, either with NA Genogroup IV strains isolated from Pacific salmonids or from Pacific marine fish, have demonstrated low pathogenicity (Meyers \& Winton 1995, Follett et al. 1997, Traxler et al. 1999; reviewed by Skall et al. 2005). Although the VHSV from freshwater drum was assigned to the same lineage as the NA and Japanese isolates (Genogroup IV) by phylogenetic analysis using Neighbour-joining distance methods, there was sufficient sequence divergence of this isolate compared to the other representatives of the group, to suggest that U13653 belongs to a distinct subgroup of NA VHSV isolates. The existence of 2 subgroups within VHSV Genogroup IV is supported by a bootstrap value of $>99 \%$, but a more comprehensive phylogenetic analysis using sequence data for other genes would be required to confirm this. If the freshwater drum isolate is sufficiently genotypically distinct from other known Genogroup IV isolates, this may mean that the conclusions drawn from these Pacific NA studies regarding the pathogenicity of VHSV Group IV may not be applicable to the Great Lakes isolate. Although controversial, it has been proposed that the VHSV Genogroup I freshwater isolates are related to (implied to be potentially derived from) Genogroup I marine isolates (Snow et al. 1999). To date, VHSV Genogroup IV has not impacted salmonids in the Great Lakes drainage area. However, the potential for development of genetic variants (Steinhauer \& Holland 1997), the ongoing presence of VHSV in the Great Lakes in multiple species of fish, and the hori- zontal waterborne transmission of the virus (Chilmonczyk et al. 1995), raise concerns about salmonid culture in the Great Lakes and beyond. Increased surveillance and alteration of stocking practices, etc., will be required initially, but a substantial impact on fish health may require more invasive management/ control practices similar to those in Europe.

Ongoing work involves a pathological description of VHSV in the other species affected to date and infection studies with this isolate to help to predict the impact on cultured salmonids in the Great Lakes.

Acknowledgements. The Fish Pathology Laboratory is part of the Canadian Cooperative Wildlife Health Centre. Thanks to Dr. D. Groman for facilitating identification and analysis, and L. Cousto for assistance with the literature review. Special thanks for their efforts to R. Stevenson and S. Lord from the Fish Health Laboratory, C. Ward at the University of Guelph and to L. Miller-Dodd in the Ontario Ministry of Natural Resources.

\section{LITERATURE CITED}

Batts WN, Winton JR (1998) Viral hemorrhagic septicemia virus RT-nPCR assay. In: Lauerman LH (ed) Nucleic acid amplification assays for diagnosis of animal diseases. Am Assoc Vet Lab Diag, St. Paul, MN

Brudeseth BE, Castric J, Evensen O (2002) Studies on pathogenesis following single and double infection with viral hemorrhagic septicemia virus and infectious hematopoietic necrosis virus in rainbow trout (Onchorhynchus mykiss). Vet Pathol 39:180-189

Brudeseth BE, Raynard RS, King JA, Evensen O (2005) Sequential pathology after experimental infection with marine viral hemorrhagic septicemia virus isolates of low and high virulence in turbot (Scophthalmus maximus). Vet Pathol 42:9-18

Brunson R, True K, Yaney J (1989) VHS virus isolated at Makah National Fish Hatchery. Am Fish Soc Fish Health Newsl 17:3-4

Chilmonczyk S, Voccia I, Monge D (1995) Pathogenesis of viral hemorrhagic septicemia virus: cellular aspects. Vet Res 26:505-511

Dixon PF, Avery S, Chambers E, Feist S and 7 others (2003) Four years of monitoring for fish viruses in marine waters around the UK. Dis Aquat Org 54:175-186

Dorson M, Quillet E, Hollebecq MG, Torhy C, Chevassus B (1995) Selection of rainbow trout resistant to viral hemorrhagic septicemia virus and transmission of resistance by gynogenesis. Vet Res 26:361-368

Einer-Jensen K, Ahrens P, Forsberg R, Lorenzen N (2004) Evolution of the fish rhabdovirus VHSV. J Gen Virol 85: $1167-1179$

Elsayed E, Faisal M, Thomas M, Whelan G, Batts W, Winton J (2006) Isolation of viral hemorrhagic septicemia virus from muskellunge, Esox masquinongy (Mitchell), in Lake St. Clair, Michigan, USA reveals a new sublineage of the North American genotype. J Fish Dis 29:611-619

Evensen O, Meier W, Wahli T, Olense NJ, Jorgensen PEV, Hastein T (1994) Comparison of immunohistochemistry and virus cultivation for detection of viral hemorrhagic septicemia virus in experimentally infected rainbow-trout Onchorhynchus mykiss. Dis Aquat Org 20:101-109 
Follett JE, Meyers TR, Burton TO, Geesin JL (1997) Comparative susceptibilities of salmonid species in Alaska to infectious hematopoietic necrosis virus (IHNV) and North American viral hemorrhagic septicemia virus (VHSV). J Aquat Anim Health 9:34-40

Gentry RD (1978) Introduction to calculus for the biological sciences. Addison-Wesley, Don Mills

Hayat MA (1970) Principles and techniques of electron microscopy - Biological applications, Vol 1. Van Nostrand Reinhold, New York

Hedrick RP, Batts WN, Yun S, Traxler GS, Kaufman J, Winton JR (2003) Host and geographic range extensions of the North American strain of viral hemorrhagic septicemia virus. Dis Aquat Org 55:211-220

Hopper K (1989) The isolation of VHSV from Chinook salmon at Glenwood Springs, Orcas Island, Washington. Am Fish Soc Fish Health Newsl 17:1

Isshiki T, Nishizawa T, Kobayashi T, Nagano T, Miyazaki T (2001) An outbreak of VHSV (viral hemorrhagic septicemia virus) infection in farmed Japanese flounder Paralichthys olivaceus in Japan. Dis Aquat Org 47:87-99

Kumar S, Tamura K, Nei M (2004) MEGA3: integrated software for molecular evolutionary genetics analysis and sequence alignment. Brief Bioinform 5:150-163

Lorenzen N, Lorenzen E, Einer-Jensen K (2001) Immunity to viral hemorrhagic septicemia (VHS) following DNA vaccination of rainbow trout at an early life-stage. Fish Shell Immunol 11:585-591

Marty GD, Freiberg EF, Meyers TR, Wilcock J, Farver TB, Hinton DE (1998) Viral hemorrhagic septicemia virus, Ichthyophonus hoferi, and other causes of morbidity in Pacific herring Clupea pallasi spawning in Prince William Sound, Alaska, USA. Dis Aquat Org 32:15-40

Meyers TR, Winton JR (1995) Viral hemorrhagic septicemia virus in North America. Annu Rev Fish Dis 5:3-24

Meyers TR, Short S, Lipson K (1999) Isolation of the North American strain of viral hemorrhagic septicemia virus (VHSV) associated with epizootic mortality in two new host species of Alaskan marine fish. Dis Aquat Org 38: 81-86

Neukirch M (1986) Demonstration of persistent viral hemorrhagic septicemia virus (VHS) in rainbow trout after experimental waterborne infection. J Vet Med 33:471-476

Nishizawa $T$, Iida $H$, Takano $R$, Isshiki $T$, Nakajima $K$, Muroga K (2002) Genetic relatedness among Japanese, American and European isolates of viral hemorrhagic septicemia virus (VHSV) based on partial G and P genes. Dis Aquat Org 48:143-148

Editorial responsibility: Jo-Ann Leong,

Kaneohe, Hawaii, USA
Olivier G (2002) Disease interactions between wild and cultured fish - perspectives from the American Northeast (Atlantic provinces). Bull Eur Assoc Fish Pathol 22: 103-109

Sindermann CJ (1990) Mass mortalities of marine fish. In: Sinderman CJ (ed) Principal diseases of marine fish and shellfish, 2nd edn, Vol 1. Diseases of marine fish. Academic Press, New York, p 375-393

Skall HF, Olesen NJ, Mellergaard S (2005) Viral haemorrhagic septicaemia virus in marine fish and its implications for fish farming - a review. J Fish Dis 28:509-529

Snow M, Cunningham CO, Melvi WT, Kurath G (1999) Analysis of the nucleoprotein gene identifies distinct lineages of viral haemorrhagic septicaemia virus within the European marine environment. Virus Res 3:35-44

Snow M, Bain N, Black J, Taupin V, Cunningham CO, King JA, Skall HF, Raynard RS (2004) Genetic population structure of marine viral haemorrhagic septicemia virus (VHSV). Dis Aquat Org 61:11-21

Steinhauer DA, Holland JJ (1997) Rapid evolution of RNA viruses. Annu Rev Microbiol 41:409-433

Stone DM, Way K, Dixon PF (1997) Nucleotide sequence of the glycoprotein gene of viral haemorrhagic septiceaemia (VHS) viruses from different geographic areas: a link between VHS in farmed fish species and viruses isolated from North Sea cod (Gadus morhua L.). J Gen Virol 78: $1319-1326$

Strømmen HK, Stone DM (1997) Detection of viral haemorrhagic septicaemia (VHS) virus in fish tissues by seminested polymerase chain reaction. In: Barnes AC, Davidson GA, Hiney MP, McIntosh D (eds) Methodology in fish diseases research. Fisheries Research Services, Aberdeen, p 203-209

Traxler GS, Keiser D, Richard J (1999) Mass mortality of pilchard and herring associated with viral hemorrhagic septicemia virus in British Columbia, Canada. Am Fish Soc Fish Health Newsl 27:3-4

Walker PD (1990) Clostridium. In: Carter GR, Cole JR (eds) Diagnostic procedures in veterinary bacteriology and mycology, 5th edn. Academic Press, New York, p 229-251

Walker PJ, Benmansour A, Dietzgen R, Fang RX and 6 others (2000) Family Rhabdoviridae. In: van Regenmortel MHV, Fauquet CM, Bishop DHL, Carstens EB and 7 others (eds) Virus taxonomy; classification and nomenclature of viruses. Academic Press, San Diego, CA, p 563-583

Winton JR, Batts WN, Nishizawa T (1989) Characterization of the first North American isolates of viral hemorrhagic septicemia virus. Am Fish Soc Fish Health Newsl 17:2-3

Submitted: June 14, 2006; Accepted: January 24, 2007

Proofs received from author(s): June 17, 2007 